Article

\title{
Comprehensive Biological and Chemical Evaluation of Two Seseli Species (S. gummiferum and S. transcaucasicum)
}

\author{
Gokhan Zengin ${ }^{1, *} * \mathbb{D}$, Dejan Stojković ${ }^{2, *}{ }^{\mathbb{D}}$, Mohamad Fawzi Mahomoodally ${ }^{3}{ }^{(}$, Bibi Sharmeen Jugreet ${ }^{3}(\mathbb{D}$, \\ Mehmet Yavuz Paksoy ${ }^{4}$, Marija Ivanov ${ }^{2}\left(\mathbb{D}\right.$, Uroš Gašić ${ }^{2}\left(\mathbb{D}\right.$, Monica Gallo ${ }^{5}$ (i) and Domenico Montesano ${ }^{6, *(1)}$
}

1 Department of Biology, Science Faculty, Selcuk University, 42130 Konya, Turkey

2 Department of Plant Physiology, Institute for Biological Research "Siniša Stanković" —National Institute of Republic of Serbia, University of Belgrade, Bulevar Despota Stefana 142, 11000 Belgrade, Serbia; marija.smiljkovic@ibiss.bg.ac.rs (M.I.); uros.gasic@ibiss.bg.ac.rs (U.G.)

3 Department of Health Sciences, Faculty of Medicine and Health Sciences, University of Mauritius, Réduit 80837, Mauritius; f.mahomoodally@uom.ac.mu (M.F.M.); sharmeenjugs@gmail.com (B.S.J.)

4 Department of Medical Services and Techniques, Medical Documentation and Secretaryship Programme, Tunceli Vocational School, Munzur University, 62000 Tunceli, Turkey; mypaksoy@gmail.com

5 Department of Molecular Medicine and Medical Biotechnology, University of Naples Federico II, Via Pansini 5, 80131 Naples, Italy; mongallo@unina.it

6 Department of Pharmacy, University of Naples Federico II, Via D. Montesano 49, 80131 Naples, Italy

* Correspondence: gokhanzengin@selcuk.edu.tr (G.Z.); dejanbio@ibiss.bg.ac.rs (D.S.); domenico.montesano@unina.it (D.M.); Tel.: +90-332-223-2781 (G.Z.); Fax: +90-332-241-2499 (G.Z.)

Citation: Zengin, G.; Stojković, D.; Mahomoodally, M.F.; Jugreet, B.S.; Paksoy, M.Y.; Ivanov, M.; Gašić, U.; Gallo, M.; Montesano, D. Comprehensive Biological and Chemical Evaluation of Two Seseli Species (S. gummiferum and $S$. transcaucasicum). Antioxidants 2021, 10, 1510. https://doi.org/10.3390/ antiox10101510

Academic Editors: Sergio Davinelli and Giovanni Scapagnini

Received: 25 August 2021

Accepted: 20 September 2021

Published: 24 September 2021

Publisher's Note: MDPI stays neutral with regard to jurisdictional claims in published maps and institutional affiliations.

Copyright: (c) 2021 by the authors. Licensee MDPI, Basel, Switzerland. This article is an open access article distributed under the terms and conditions of the Creative Commons Attribution (CC BY) license (https:// creativecommons.org/licenses/by/ $4.0 /)$.
Abstract: Seseli L. is one of the largest genera of the Apiaceae family widely known for their traditional uses as herbal remedies. In the present study, the methanolic and water extracts of two Seseli species, $S$. gummiferum and S. transcaucasicum were evaluated for their bioactive contents and biological activities. The total phenolic and flavonoid contents in the extracts ranged from 19.09 to $24.33 \mathrm{mg}$ GAE/g and from 0.45 to $10.09 \mathrm{mg} \mathrm{RE} / \mathrm{g}$, respectively. Moreover, while narcissin was detected as the most abundant component in the methanolic extract of S. transcaucasicum $(261.40 \mu \mathrm{g} / \mathrm{g})$, chlorogenic acid was identified as the major component in all the other extracts, although a high amount was also present in the methanolic S. transcaucasicum extract (107.48-243.12 $\mu \mathrm{g} / \mathrm{g})$. The total antioxidant capacity was also determined by the phosphomolybdenum assay (0.66-1.18 mM TE/g). Other antioxidant assays such as the radical scavenging assays (DPPH: 5.51-11.45 mg TE/g; ABTS: 43.46-51.91 mg TE/g), reducing assays (CUPRAC: $41.67-53.20 \mathrm{mg}$ TE/g; FRAP: 31.26-34.14 mg TE/g), as well as the metal chelating activity assay (14.38-38.57 mg EDTAE/g) were conducted. All the extracts showed inhibitory potential against the enzyme's amylase $(0.12-0.78 \mathrm{mM} \mathrm{ACAE} / \mathrm{g})$, acetyl- and butyryl-cholinesterase (0.15-9.71 mg GALAE/g), while only the methanolic extracts acted as inhibitors of tyrosinase (107.15 and $109.37 \mathrm{mg} \mathrm{KAE/g)} \mathrm{and} \mathrm{only} \mathrm{the} \mathrm{water} \mathrm{extract} \mathrm{of} S$. gummiferum displayed anti-glucosidase activity $(0.13 \mathrm{mM} \mathrm{ACAE} / \mathrm{g})$. Interestingly, the methanolic extracts of both Seseli species showed lower cytotoxicity towards $\mathrm{HaCaT}$ cells $\left(\mathrm{IC}_{50}:>500 \mu \mathrm{g} / \mathrm{mL}\right.$ ), compared to the water extracts $\left(\mathrm{IC}_{50}\right.$ : 267.8 and $321.41 \mu \mathrm{g} / \mathrm{mL}$ ). Besides, only the methanolic extracts showed a slight wound healing effect (28.21 and 31.23\%). All extracts showed antibacterial action against Staphylococcus lugdunensis (minimum inhibitory and bactericidal concentrations: $0.025-2 \mathrm{mg} / \mathrm{mL}$ ). S. gummiferum methanolic extract, which exhibited the highest antibacterial potency was found to inhibit adhesion and invasion of S. lugdunensis to HaCaT cells as well. Taken together, this study demonstrated the two Seseli species to harbour interesting bioactive components, in particular polyphenolics and to exhibit several biological properties that could be further investigated for their potential exploitation as healing agents as supported by various traditional medicinal uses.

Keywords: Seseli; polyphenolic; antioxidant; enzyme inhibitors; antibacterial; wound healing 


\section{Introduction}

Seseli L. is an important genus comprising of many aromatic species (about 140 taxa) used in traditional medicine due to its recognized therapeutic properties. Several Seseli species are used in folk medicine as herbal drugs for several purposes including to treat common cold, inflammation, pain as well as an antiflatulent [1]. Moreover, species of this genus have been reported to possess anthelmintic, carminative, stomachic and stimulant properties [2]. Some representatives of Seseli genus have also been used in the treatment of central nervous system disorders such as epilepsy [3]. Furthermore, some members of the genus Seseli have been widely employed in traditional medicine owing to their antibacterial, antifungal, and insect repellent activities [4], while others are known as being antispasmodic and diuretic [5].

In light of the ethnobotanical uses; several studies have been conducted on the biological activities of the members of this genus. Previously, antibacterial, anticancer, anti-inflammatory and antinociceptive effects have been confirmed for several Seseli species [2,6-8]. Furthermore, a number of scientific reports have demonstrated Seseli species to contain volatile oils with important pharmacological potentials. For instance, various studies have shown essential oils from Seseli species to possess antimicrobial as well as antioxidant properties [9-11]. In another study, the safety of the essential oil from a Seseli species (S. tortuosum) was reported for doses with anti-inflammatory activity [1].

Besides, the genus Seseli is known to be rich in coumarins, a number of which are recognized for their medicinal properties [12-15]. Attempts were also made to explore the detailed underlying mechanism of coumarins isolated from Seseli species, as active pharmacological agents. Notably, the anti-inflammatory properties of samidin from $S$. resinosum through suppression of NF-jB and AP-1-mediated-genes in LPS-stimulated RAW 264.7 cells, were reported [16]. Additionally, another two new coumarins from S. resinosum, were found to exhibit anti-inflammatory effects through the inhibition of pro-inflammatory enzymes and cytokines [17]. Moreover, previously the lignans seselinone and eudesmin, isolated from the aerial parts of S. annuиm, displayed cytotoxic activity against C6 rat glioma cell cultures [18].

Hence, the scientific data collected so far on several Seseli species point out the tremendous healing potentials of these plants that can benefit human health and be used in the management of various diseases, as supported by their widespread uses in traditional medicine. To the best of our knowledge, however, the chemical composition, and biological activities of most members of the Seseli genus have not yet been investigated. Thus, in this study, the bioactive contents and polyphenolic profile of methanolic and water extracts of two such uninvestigated species of Seseli (S. gummiferum and S. transcaucasicum) were determined and their various biological potentials (antioxidant, enzyme inhibition, cytotoxic, wound healing and antibacterial properties) were evaluated.

\section{Materials and Methods}

\subsection{Plant Materials and Extraction Procedure}

Seseli species were collected in July 2020 from Turkey (S. gummiferum Pall. ex Sm.: Akseki, Antalya, Gidefi Mountain, $1800 \mathrm{~m}$ and S. transcaucasicum (Schischk.) Pimenov \& Sdobnina: Van, between Güzelsu and Başkale, Güzeldere location, $2700 \mathrm{~m}$ ). Voucher specimens were deposited in Munzur University (Voucher numbers: Paksoy 1860 and Paksoy 1414, respectively). The plant materials (aerial parts) were carefully dried in a shade place for 10 days and then they were powdered with a laboratory mill.

For each species, two solvents were used in the preparation of extracts. To prepare the methanolic extracts, the plant materials $(5 \mathrm{~g})$ were macerated with $100 \mathrm{~mL}$ of methanol in a magnetic stirrer for $24 \mathrm{~h}$ at room temperature. After that, the mixtures were filtered and then evaporated to remove the solvents. To prepare water extracts, powdered plant materials $(5 \mathrm{~g})$ were infused in boiled water $(100 \mathrm{~mL})$ for $15 \mathrm{~min}$. The obtained water extracts were filtered and then lyophilized to remove water. All extracts were stored at $4{ }^{\circ} \mathrm{C}$ until further analysis. 


\subsection{Phytochemical Composition}

Total phenolic content (TPC) and total flavonoid content (TFC) were determined according to previously described methods $[19,20]$. TPC was expressed as mg gallic acid equivalents (GAE)/g dry extract, whereas TFC was expressed as mg rutin equivalents (RE)/g dry extract.

\subsection{UHPLC(-)HESI-QqQ-MS/MS Targeted Metabolic Analysis}

Quantification of the targeted compounds was performed using Dionex Ultimate 3000 Ultra-High-Performance Liquid Chromatography (UHPLC) system (Thermo Fisher Scientific, Bremen, Germany) connected to a triple-quadrupole (QqQ) mass spectrometer (MS) (TSQ Quantum Access Max, Thermo Fisher Scientific, Basel, Switzerland).

Syncronis C18 aqua analytical column $(100 \times 2.1 \mathrm{~mm})$ with $1.7 \mu \mathrm{m}$ particle size (Thermo Fisher Scientific, Waltham, MA, USA) was used for the chromatographic separation. The flow rate and composition of the mobile phases, as well as the gradient elution program were previously described by Radović, et al. [21]. The mass detector was equipped with heated electrospray ionization (HESI) source operating in the negative ionization mode. The parameters of HESI source and the other mass detector settings were previously described in the study of Božunović, et al. [22]. The compounds of interest were identified and quantified by direct comparison with commercial standards. For each compound, the multiple mass spectrometric scanning modes, including full scanning (FS), and product ion scanning (PIS) were performed. The collision-induced fragmentation experiments were performed using argon as the collision gas, and the collision energy was varied depending on the compound. The time-selected reaction monitoring (tSRM) experiments for quantitative analysis were performed using two $\mathrm{MS}^{2}$ fragments for each compound that were previously defined as dominant in the PIS experiments. The total amounts of each compound were evaluated by calculation of the peak areas and are expressed as $\mu \mathrm{g} / \mathrm{g}$.

\subsection{Antioxidant and Enzyme Inhibitory Assays}

By referring to the methods of Uysalet al. [20], the radical scavenging and reducing power abilities of the extracts were evaluated using ABTS, DPPH, CUPRAC and FRAP assays. Likewise, ferrous ion chelating and phosphomolybdenum assays were performed. The results were expressed as equivalents of Trolox (TE) or ethylenediaminetetraacetic acid (EDTA). The ability of the extracts to inhibit the effects of a panel of key enzymes, such as cholinesterases, $\alpha$-glucosidase, $\alpha$-amylase and tyrosinase, were investigated according to the protocols described by Grochowski et al. [19]. The enzyme inhibitory activities of the extracts were expressed as equivalents of acarbose for $\alpha$-glucosidase and $\alpha$-amylase, galantamine for cholinesterases, and kojic acid for tyrosinase.

\subsection{Cytotoxicity towards HaCaT Cells}

The cytotoxic effect of the extracts was investigated on a spontaneously immortalized skin keratinocyte cell line $(\mathrm{HaCaT})$ by employing crystal violet dye, as reported previously [23], with some modifications. PBS solution was used to dissolve the extracts $(8 \mathrm{mg} / \mathrm{mL})$. HaCaT cells were prepared for the assay according to published procedures [24]. The results were expressed as $\mathrm{IC}_{50}$ value, indicating $50 \%$ of cell viability when compared with untreated control. The solvent was used as a negative control.

\subsection{Scratch-Wound Healing Assay}

The procedures used for the assay were described in detail by Stojković, et al. [25] and the experiment was performed with some modifications. HaCaT cells were grown until confluence was reached. Pipetman tips of $200 \mu \mathrm{L}$ were used to scratch the cell's monolayer. Reduced DMEM was used, containing $\mathrm{IC}_{25}$ concentration of extracts as determined in the cytotoxicity assay. Cell migration was monitored with Nikon Eclipse TS2 (Amsterdam, The Netherlands) $24 \mathrm{~h}$ after the wound was made and treated. Untreated control was used to measure wound closure under these conditions, without the addition of extracts. 
The results were presented as percentages of wound closure during the exposure to the tested extracts.

\subsection{Antibacterial Activity}

The strain used in the assay was the skin isolate, Staphylococcus lugdunensis. The antibacterial activity of different extracts was evaluated by the microdilution method in 96 well microtiter plates. The minimum inhibitory concentrations (MIC) and minimal bactericidal concentrations (MBC) of the bacterial species were determined as described by Kostić, et al. [26]. Streptomycin was used as the positive control.

\subsection{HaCaT Cell Invasion and Adhesion Assay}

For further assays, the methanolic extract of $S$. gummiferum was selected due to its lowest MIC towards S. lugdunensis $(0.5 \mathrm{mg} / \mathrm{mL})$ compared to other extracts determined in the antibacterial assay. Assessment of the extract ability to reduce adhesion capacity of S. lugdunensis towards HaCaT cells was determined as described in the study of Ahmed et al. [24], with some modifications.

For adhesion assay, the confluent monolayer of HaCaT cells was grown in 24-well plates with adhesive bottom. Medium was removed and fresh FBS free DMEM with extract was added and plate was incubated at $37^{\circ} \mathrm{C}$ for $15 \mathrm{~min}$. Afterwards $100 \mu \mathrm{L}$ of $S$. lugdunensis culture $\left(10^{8} \mathrm{CFU} / \mathrm{mL}\right)$ was added to the wells. The mixture was incubated at $37^{\circ} \mathrm{C}$ for $1 \mathrm{~h}$. The cells were washed three times with FBS free DMEM and lysis of the HaCaT cells was carried out with $1 \mathrm{~mL}$ of 1\% (v/v) Tween-20 (SigmaAldrich, Darmstadt, Germany) at $37^{\circ} \mathrm{C}$ for $30 \mathrm{~min}$. Subsequently, dilutions of the S. lugdunensis suspension in each well were made and seeded on Trypton Soy Agar plates. After $18 \mathrm{~h}$ incubation at $37^{\circ} \mathrm{C}$, the number of viable cells was determined and compared to the control (untreated HaCaT cells).

For invasion assay, parallel experiments were carried out as described above. The exception was that in this part the plates were incubated with $S$. lugdunensis for $2 \mathrm{~h}$ in order to allow enough time for the bacteria to invade HaCaT cells, after which the cells were treated with gentamicin $(300 \mu \mathrm{g} / \mathrm{mL})$ for $1 \mathrm{~h}$. Adherent cells were washed with FBS free DMEM three times, followed by incubation of the infected cells with $1 \%(v / v)$ Tween-20. Samples were diluted and plated on Trypton Soy Agar plates. After $18 \mathrm{~h}$ incubation at $37^{\circ} \mathrm{C}$, the number of viable cells was determined and compared to the control (untreated HaCaT cells).

\subsection{Statistical Analysis}

Results were presented as the mean \pm standard deviation (SD) and significant differences $(p<0.05)$ were determined by One-way ANOVA with post-hoc Tukey HSD, using Xlstat 2018 program.

\section{Results and Discussion}

In the current study, extracts of two Seseli species were tested for their bioactive contents in terms of polyphenolic constituents. In order to assess the phenolic content, both spectrophotometric standard methods and HPLC techniques were used. The Seseli extracts in present study yielded TPC ranging from 19.09 to $24.33 \mathrm{mg}$ GAE/g and TFC ranging from 0.45 to $10.09 \mathrm{mg} \mathrm{RE} / \mathrm{g}$ (Table 1 ). The water extracts were found to yield much lower TFC than the methanolic extracts. In the phosphomolybdenum assay, the highest antioxidant capacity was obtained for the methanolic extract of $S$. transcaucasicum, followed by the methanolic extract of $S$. gummiferum $(1.18 \pm 0.12$ and $0.90 \pm 0.09 \mathrm{mmol} \mathrm{TE} / \mathrm{g}$, respectively). The total antioxidant capacity of the water extracts of $S$. gummiferum and S. transcaucasicum were 0.78 and $0.66 \mathrm{mmol} \mathrm{TE} / \mathrm{g}$, respectively (Table 1 ). The higher total antioxidant capacity of the methanolic extracts could be related to the higher TFC and slightly higher TPC than the water extracts. 
Table 1. Total bioactive contents and total antioxidant capacity (by phosphomolybdenum assay) of the tested extracts.

\begin{tabular}{cccc}
\hline Extracts & TPC $(\mathbf{m g ~ G A E} / \mathbf{g})$ & TFC $(\mathbf{m g}$ RE/g) & PDA $(\mathbf{m m o l}$ TE/g) \\
\hline S. gummiferum-MeOH & $24.33 \pm 0.84^{\mathrm{a}}$ & $7.33 \pm 0.50^{\mathrm{b}}$ & $0.90 \pm 0.09^{\mathrm{b}}$ \\
S. gummiferum-Water & $21.18 \pm 0.14^{\mathrm{b}}$ & $0.48 \pm 0.04^{\mathrm{c}}$ & $0.78 \pm 0.09^{\mathrm{b}}$ \\
S. transcaucasicum-MeOH & $23.72 \pm 0.69^{\mathrm{a}}$ & $10.09 \pm 0.20^{\mathrm{a}}$ & $1.18 \pm 0.12^{\mathrm{a}}$ \\
S. transcaucasicum-Water & $19.09 \pm 0.09^{\mathrm{c}}$ & $0.45 \pm 0.04^{\mathrm{c}}$ & $0.66 \pm 0.11^{\mathrm{b}}$ \\
\hline
\end{tabular}

Values are reported as mean \pm SD. MeOH: Methanol; TPC: total phenolic content; TFC: total flavonoid content; GAE: Gallic acid equivalent; RE: rutin equivalent; TE: trolox equivalent. PDA: Phosphomolybdenum assay. Different letters indicate significant differences among the tested extracts $(p<0.05)$.

Indeed, the choice of solvents is one the most important steps in phytochemical studies and at this point, the chemical composition and biological activities of the tested Seseli species were influenced by the solvent used. These findings could be a starting point for further studies on the tested Seseli species.

The TPC and TFC present in other Seseli species have also been determined. Notably, the TPC and TFC in the methanolic extracts of S. pallasii Besser, S. libanotis (L.) Koch ssp. libanotis and S. libanotis (L.) Koch ssp. intermedium (Rupr.) P. W. Ball ranged from 84.04-87.53 mg GAE/g and 4.76-19.38 mg quercetin/g, respectively, in the study of Matejić and colleagues [27]. In another study, the contents of total phenolics and flavonoids of various extracts of $S$. rigidum Waldst. Et Kit. (aqueous, acetone, ethyl acetate, methanol and petroleum ether) were evaluated, whereby the acetone extract was found to have the highest TPC and TFC (102.13 mg GAE/g and $291.58 \mathrm{mg}$ RE/g, respectively) [28]. The different levels of bioactive contents could be explained by geographical and climatic factors (altitude, rainfall, etc.) and experimental differences (concentration, expressed unit, etc.) $[29,30]$. In addition, most scientists have recently given up the use of the FolinCiocalteu assay because not only phenolics but also other phytochemicals could play a reducing role in the assay [31]. Thus, the content of total phenolics has to be confirmed by at least one chromatographic technique and for this reason, phenolics were identified and quantified using HPLC, in the present study.

Based on HPLC quantification, a total of 18 constituents were found to be present in all the studied extracts except $S$. gummiferum water extract, in which only 17 compounds were identified. While naringenin was present in all the other extracts, it was absent in the S. gummiferum water extract. Chlorogenic acid was detected as the major constituent in methanolic and water extracts of S. gummiferum, as well as water extract of S. transcaucasicum (210.96, 198.53 and $107.48 \mu \mathrm{g} / \mathrm{g}$, respectively). On the other hand, narcissin was found to be the most abundant constituent in the methanolic extract of $S$. transcaucasicum $(261.40 \mu \mathrm{g} / \mathrm{g})$, although chlorogenic acid was also present in high amount $(243.12 \mu \mathrm{g} / \mathrm{g})($ Table 2$)$. The UHPLC-DAD chromatograms at $280 \mathrm{~nm}$, with some labelled peaks of polyphenols, are presented in Figure S1 (Supplementary Material). Interestingly, the methanolic extracts of the two Seseli species were observed to contain higher amounts of chlorogenic acid and narcissin compared to the water extracts, thus implying that methanol was a better solvent for extraction of these compounds than water. Accumulating evidence has demonstrated chlorogenic acid to display many biological properties, including the ability to modulate glucose and lipid metabolism in vivo in both healthy and genetically metabolic disordered conditions [32-34]. Other researchers have also previously shown interests in elucidating the chemical profile of different extracts and oils from Seseli species [35-39].

The antioxidant properties of plant-derived products have become an indispensable tool in determining their efficacy as treatments [4]. An imbalance between the synthesis and accumulation of reactive oxygen species (ROS) in cells and tissues, as well as the ability of a biological system to de-toxify these reactive products, causes oxidative stress [40]. Chronic illnesses such as diabetes, cardiovascular disease, neurodegenerative disease, and cancer all include oxidative stress as a pathogenesis factor [41]. Plants have been discovered to have an intrinsic ability to biosynthesize a wide spectrum of non-enzymatic antioxidants that can reduce ROS-induced oxidative damage [42]. As a result, plant-derived antioxidant 
molecules and their antioxidant defence mechanisms can help in the prevention of various illnesses. Antioxidant capacity is widely measured using in vitro antioxidant assays, which allow the examination of a wide range of potential antioxidant processes exhibited by phytochemicals such as polyphenols [43].

Table 2. Polyphenolic constituents detected in extracts ( $\mu \mathrm{g} / \mathrm{g}$ extract) by means of UHPLC(-)HESI-QqQ-MS/MS.

\begin{tabular}{ccccc}
\hline $\begin{array}{c}\text { Polyphenolic Constituents } \\
(\mu \mathrm{g} / \mathrm{g})\end{array}$ & S. gummiferum-MeOH & S.gummiferum-Water & S. transcaucasicum-MeOH & S. transcaucasicum-Water \\
\hline Gallic acid & 37.81 & 22.27 & 31.94 & 8.70 \\
Protocatechuic acid & 61.33 & 66.32 & 73.02 & 66.25 \\
Syringic acid & 51.53 & 53.35 & 57.80 & 54.19 \\
Aesculin & 56.41 & 59.77 & 70.60 & 58.97 \\
Epigallocatechin & 51.28 & 60.91 & 75.05 & 40.98 \\
Chlorogenic acid & 210.96 & 198.53 & 243.12 & 4.48 \\
Aesculetin & 8.05 & 6.89 & 11.15 & 4.77 \\
Caffeic acid & 11.86 & 11.65 & 15.37 & 4.38 \\
Isoorientin & 3.80 & 3.10 & 5.79 & 26.00 \\
Rutin & 15.22 & 14.42 & 54.52 & 24.67 \\
p-Coumaric acid & 18.69 & 27.16 & 28.93 & 8.73 \\
Isoquercetin & 8.67 & 6.87 & 21.56 & 61.29 \\
Narcissin & 202.13 & 57.61 & 4.40 & 2.26 \\
Quercitrin & 2.20 & 2.49 & 2.59 & 2.73 \\
Rosmarinic acid & 8.20 & 4.91 & 3.33 & 2.45 \\
Apigenin & 2.27 & 2.35 & 3.33 & 9.80 \\
Naringenin & 2.05 & NF & 9.49 & \\
Hispidulin & 5.18 & 1.94 & & \\
\hline NF-not found & & & & \\
\hline
\end{tabular}

In the present investigation, all extracts were found to possess radical scavenging potential (DPPH: 5.51-11.45 mg TE/g; ABTS: 43.46-51.91 mg TE/g) (Table 3). However, extracts of $S$. gummiferum showed relatively higher scavenging potential compared to $S$. transcaucasicum. Moreover, reducing activity was demonstrated in both CUPRAC and FRAP assays (41.67-53.20 mg TE/g and 31.26-34.14 mg TE/g, respectively) (Table 3). In the CUPRAC assay particularly, the methanolic extracts displayed higher reducing potential compared to the water extracts. Metal chelating activity was also determined with activity ranging from 14.38 to $38.57 \mathrm{mg}$ EDTAE/g (Table 3). Interestingly, the water extracts showed higher chelating potential than the methanolic extracts.

Table 3. Antioxidant properties of the tested extracts.

\begin{tabular}{|c|c|c|c|c|c|}
\hline Extracts & $\begin{array}{c}\text { DPPH } \\
\text { (mg TE/g) }\end{array}$ & $\begin{array}{c}\text { ABTS } \\
\text { (mg TE/g) }\end{array}$ & $\begin{array}{l}\text { CUPRAC } \\
\text { (mg TE/g) }\end{array}$ & $\begin{array}{c}\text { FRAP } \\
\text { (mg TE/g) }\end{array}$ & $\begin{array}{c}\text { MCA } \\
\text { (mg EDTAE/g) }\end{array}$ \\
\hline S. gummiferum-MeOH & $10.24 \pm 0.67^{a, b}$ & $51.91 \pm 0.81^{\mathrm{a}}$ & $53.20 \pm 2.38^{a}$ & $33.32 \pm 0.57^{\mathrm{a}, \mathrm{b}}$ & $15.93 \pm 0.45^{c}$ \\
\hline S. gummiferum-Water & $11.45 \pm 0.77^{\mathrm{a}}$ & $46.78 \pm 1.03^{b}$ & $44.28 \pm 1.18^{b, c}$ & $34.14 \pm 0.14^{\mathrm{a}}$ & $22.76 \pm 0.36^{b}$ \\
\hline S. transcaucasicum-MeOH & $5.51 \pm 0.94^{\mathrm{c}}$ & $43.46 \pm 0.97^{c}$ & $48.07 \pm 1.58^{b}$ & $32.44 \pm 0.99 \mathrm{~b}, \mathrm{c}$ & $14.38 \pm 0.24^{\mathrm{d}}$ \\
\hline S. transcaucasicum-Water & $8.53 \pm 0.38^{b}$ & $45.70 \pm 0.88^{b, c}$ & $41.67 \pm 0.33^{c}$ & $31.26 \pm 0.52^{c}$ & $38.57 \pm 0.93^{\mathrm{a}}$ \\
\hline
\end{tabular}

Values are reported as mean \pm SD. ABTS: 2,2'-azino-bis(3-ethylbenzothiazoline-6-sulphonic acid; DPPH: 1,1-diphenyl-2-picrylhydrazyl; CUPRAC: Cupric reducing antioxidant capacity; FRAP: Ferric reducing antioxidant power; MCA: Metal chelating activity. MeOH: Methanol; TE: Trolox equivalent; EDTAE: EDTA equivalents. Different letters indicate significant differences among the tested extracts $(p<0.05)$.

Several Seseli species have been previously validated for their antioxidant capacity. In the study of Önder, et al. [44], the radical scavenging activity and anti-lipid peroxidation of the ethyl acetate and methanolic extracts obtained from several Seseli species growing in Turkey namely, S. andronakii, S. campestre, S. corymbosum, S. gummiferum subsp. gummiferum, S. hartvigii, S. libanotis, S. petraeum, S. arenarium, S. resinosum, and S. tortuosum were evaluated (in DPPH assay: $\mathrm{IC}_{50}=0.086-4.27 \mathrm{mg} / \mathrm{mL}$; in lipid peroxidation assay: \% inhibition of $43-95 \%$ at $5 \mathrm{mg} / \mathrm{mL}$ ). Extracts of different polarity obtained from various plant parts (root, leaf, flower and fruit) of $S$. rigidum were also studied by different antioxidant assays 
such as DPPH and ABTS radical scavenging activity, total reducing power method as well as via total contents of flavonoids and polyphenols [37].

Indeed, it is important to point out that the performed assays are not independent of solvents used. For example, Foti [45] reviewed the solubility and kinetic properties of DPPH and DPPH was found to be poorly soluble in apolar solvents and generally polar solvents, especially methanol or ethanol, which are the most preferred for preparing DPPH. Moreover, ABTS is not a stable radical and it has been used to evaluate both lipophilic and hydrophobic antioxidant components in plant extracts. As another insight, FRAP and CUPRAC assays are $\mathrm{pH}$ dependent. Taken together, the antioxidant results could not be explained by just one factor as it could be influenced by several factors [46].

However, the phenolic compounds might be the major contributors to the obtained antioxidant results. This can be attributed to the presence of some phenolics, particularly chlorogenic acid, narcissin, epigallocatechin and aesculin. These compounds have been reported by several authors as significant antioxidants. For example, chlorogenic acid acts as a hydrogen donator to scavenge free radicals and inhibit oxidation reactions [47,48]. Noaves et al. [49] reported that narcissin exhibited remarkable ABTS radical scavenging ability with the value of $0.88 \mathrm{~mol} \mathrm{TE} / \mathrm{mol}$ of flavonol. In another study conducted by He et al. [50], different catechin derivatives were investigated for antioxidant properties and epigallocatechin displayed stronger DPPH radical scavenging ability than gallocatechin, epicatechin and catechin. In this sense, the number and position of the hydroxyl groups in the phenolic ring are directly related to their antioxidant capacities [51].

The use of enzyme inhibitors in drug discovery has become a common practice in pharmacology. Enzymes play a role in a wide variety of human diseases and a number of specific enzyme inhibitors have been developed to inhibit their activity and therefore act as therapeutic agents [52].

The enzyme cholinesterase (ChE) is an important therapeutic target for Alzheimer's disease (AD). The deterioration of cholinergic neurons in the brain and the loss of neurotransmission are the main causes of the decline in cognitive function in AD patients. Thus, one of the potential therapeutic strategies is to boost the cholinergic levels in the brain by inhibiting the biological activity of ChE [53]. In the current investigation, all the studied extracts inhibited both cholinesterases and the same order of inhibitory potency of the extracts was observed against the enzymes, that is $S$. transcaucasicum-MeOH $>$ S. gummiferum$\mathrm{MeOH}>$ S. gummiferum-Water $>$ S. transcaucasicum-Water (AChE: 0.15-4.53 mg GALAE/g and BChE: 1.66-9.71 mg GALAE/g) (Table 4). In particular, the methanolic extracts possessed higher anti-cholinesterase activities compared to the water extracts. When chemical components and cholinesterase inhibitory properties were analysed, the presence of some phenolic components was found to support the observed activity. For example, chlorogenic and caffeic acids were reported as significant acetylcholinesterase inhibitors in an earlier study performed by Oboh et al. [54]. In addition, rosmarinic acid [55], gallic acid [56] and rutin [57] showed remarkable cholinesterase inhibitory effects.

Inhibition of tyrosinase, a copper-containing enzyme that catalyses the essential stages of melanogenesis, is one of the most popular ways to control skin pigmentation [58]. Current research has focused on both synthetic and natural sources for reducing melanin formation. With respect to natural substances, many plant species have been found to be major sources of skin lightening agents $[59,60]$. In the present study, only the methanolic extracts were found to possess anti-tyrosinase activity, while the water extracts were inactive against tyrosinase. For instance, the tyrosinase inhibitory activity of the methanolic extracts of S. transcaucasicum and S. gummiferum was recorded as $109.37 \pm 0.38 \mathrm{mg} \mathrm{KAE} / \mathrm{g}$ and $107.15 \pm 1.38 \mathrm{mg} \mathrm{KAE} / \mathrm{g}$, respectively (Table 4). The higher tyrosinase inhibitory properties can be associated with higher total phenolics in the methanolic extracts. In particular, the presence of some phenolics, including chlorogenic, caffeic and rosmarinic acids might have contributed to the observed tyrosinase inhibitory abilities. Consistent with our presented results, these compounds have been reported as significant tyrosinase 
inhibitors in previous studies [61-63]. Taken together, the tested methanolic extracts could be considered as a source of natural tyrosinase inhibitors for cosmeceutical applications.

Table 4. Enzyme inhibitory effects of the tested extracts.

\begin{tabular}{|c|c|c|c|c|c|}
\hline Extracts & $\begin{array}{c}\text { AChE } \\
\text { (mg GALAE/g) }\end{array}$ & $\begin{array}{c}\text { BChE } \\
\text { (mg GALAE/g) }\end{array}$ & $\begin{array}{l}\text { Tyrosinase } \\
\text { (mg KAE/g) }\end{array}$ & $\begin{array}{c}\text { Amylase } \\
\text { (mmol ACAE/g) }\end{array}$ & $\begin{array}{c}\text { Glucosidase } \\
\text { (mmol ACAE/g) }\end{array}$ \\
\hline S. gummiferum-MeOH & $3.48 \pm 0.09^{b}$ & $8.90 \pm 0.35^{\mathrm{a}}$ & $107.15 \pm 1.38^{b}$ & $0.78 \pm 0.01^{\mathrm{a}}$ & na \\
\hline S. gummiferum-Water & $0.35 \pm 0.08^{c}$ & $6.52 \pm 0.97^{b}$ & na & $0.12 \pm 0.02^{b}$ & $0.13 \pm 0.01$ \\
\hline S. transcaucasicum-MeOH & $4.53 \pm 0.19^{\mathrm{a}}$ & $9.71 \pm 0.47^{\mathrm{a}}$ & $109.37 \pm 0.38^{\mathrm{a}}$ & $0.78 \pm 0.01^{\mathrm{a}}$ & na \\
\hline S. transcaucasicum-Water & $0.15 \pm 0.05^{\mathrm{d}}$ & $1.66 \pm 0.17^{c}$ & na & $0.12 \pm 0.01^{b}$ & na \\
\hline
\end{tabular}

Values are reported as mean \pm SD. AChE: acetylcholinesterase; BChE: butyrylcholinesterase; MeOH: Methanol; GALAE: Galantamine equivalent; KAE: Kojic acid equivalent; ACAE: Acarbose equivalent; Na: not active. Different letters indicate significant differences among the tested extracts $(p<0.05)$.

The inhibition of $\alpha$-glucosidase and $\alpha$-amylase, enzymes involved in carbohydrate digestion, can considerably minimize the postprandial glucose level and hence can be a useful technique in the control of blood glucose levels in type 2 diabetic individuals [64]. Therefore, several studies have been performed to establish the antidiabetic potential of extracts or isolated components from different plant species $[65,66]$. In this study, all extracts were found to inhibit amylase exclusively, except the water extract of S. gummiferum which also inhibited glucosidase $(0.13 \pm 0.01 \mathrm{mmol}$ ACAE/g). Moreover, the methanolic extracts showed higher anti-amylase activity compared to the water extracts. Besides, both methanolic extracts and both water extracts showed the same inhibitory activity against the amylase $(0.78 \mathrm{mmol} \mathrm{ACAE} / \mathrm{g}$ and $0.12 \mathrm{mmol} \mathrm{ACAE} / \mathrm{g}$, respectively) (Table 4). Recently, several papers have indicated that phenolics are of great interest as carbohydratehydrolyzing enzyme inhibitors. For example, chlorogenic acid exhibited a good amylase inhibition action with an $\mathrm{IC}_{50}$ value of $0.498 \mathrm{mg} / \mathrm{mL}$ [67]. Similar findings were also reported for rosmarinic, caffeic and gallic acids [67-69]. Interestingly, many flavonoids have been found to possess anti-carbohydrate hydrolysing effects. Tadera, et al. [70], for instance, tested several flavonoid compounds for their inhibitory activity against $\alpha$-amylase. They showed that luteolin, myricetin, and quercetin were potent inhibitors against porcine pancreatic $\alpha$-amylase and that the potency of the inhibition correlated with the number of hydroxyl groups on the B ring of the flavonoid scaffold.

Overall, the methanolic extracts were revealed to be better inhibitors of the studied enzymes compared to the water extracts, which may be due to the presence of certain active compounds that were extracted in methanol and not water. Our findings could open new horizons for the development of novel pharmaceuticals using natural enzyme inhibitors and the tested Seseli species could be considered as raw materials in this sense.

As revealed by the cytotoxic studies of the extracts on $\mathrm{HaCaT}$ cells, the water extracts were found to be more cytotoxic $\left(\mathrm{IC}_{50}: 267.8 \pm 4.14 \mu \mathrm{g} / \mathrm{mL}\right.$ and $321.41 \pm 1.25 \mu \mathrm{g} / \mathrm{mL}$ for S. gummiferum and S. transcaucasicum, respectively) than the methanolic extracts $\left(\mathrm{IC}_{50}:>500 \mu \mathrm{g} / \mathrm{mL}\right)$ (Table 5).

Interestingly, previous scientific reports also investigated the cytotoxic effects of Seseli species on different cell lines, including cancer cell lines. For example, the extracts obtained from the root of $S$. petraeum showed a significant inhibitory effect on cell proliferation. The hexane extract of the root exhibited potent inhibition on A549 cancer cell growth at the 24th $\mathrm{h}\left(\mathrm{IC}_{50}: 3.432 \mathrm{mg} / \mathrm{mL}\right)$. The results also showed that the hexane extract displayed the cytotoxic effect through an arrest at the G0/G1 phase of the cell cycle and induced apoptosis as well as DNA damage in A549 cells [8]. Besides, a recent study showed that chlorogenic acid, a main compound identified in the Seseli species in the current study, did not reduce viability of human promyelocytic leukemia cells (HL-60) and human acute T-cell leukemia cells (Jurkat). Furthermore, chlorogenic acid at a concentration of $100 \mu \mathrm{M}$ induced global DNA hypomethylation, a cell-specific effect in Jurkat cells [71]. Another study showed that chlorogenic acid exhibited cytotoxic activity via hydrogen peroxide-mediated oxidation 
mechanism in human oral squamous cell carcinoma (HSC-2) and salivary gland tumor (HSG) cell lines [72].

Table 5. Cytotoxicity of extracts towards HaCaT cells.

\begin{tabular}{cc}
\hline Extracts & IC $_{\mathbf{5 0}}(\boldsymbol{\mu g} / \mathbf{m L})$ \\
\hline S. gummiferum-MeOH & $>500$ \\
S. gummiferum-Water & $267.8 \pm 4.14$ \\
S. transcaucasicum-MeOH & $>500$ \\
S. transcaucasicum-Water & $321.41 \pm 1.25$ \\
\hline
\end{tabular}

Following the cytotoxic study, the wound healing potential of the extracts was evaluated. While the methanolic extracts of both Seseli species were noted to have a wound healing effect (Relative cell migration: $31.23 \pm 2.24 \%$ and $28.21 \pm 2.64 \%$ for S. gummiferum and $S$. transcaucasicum, respectively), the water extracts did not have any effect on cell migration into the wounded area (Table 6). S. gummiferum methanolic extract showed a relatively higher wound healing effect than that of $S$. transcaucasicum. However, while wound healing effect could be noted for the methanolic extracts of these two species, it was not so prominent. Chlorogenic acid was represented by higher amounts in methanolic extracts of the Seseli species. This is interesting because the wound healing potential was noted for the extracts that contained more chlorogenic acid and narcissin. Previous findings suggested that chlorogenic acid enhanced the capillary-like tube formation of endothelial cells in an in vitro angiogenesis assay and accelerated the fibroblastic and remodelling phases [73]. It is well known that notable wound healing activity of chlorogenic acid is brought about by the enhancement of collagen synthesis via upregulation of Tumor Necrosis Factor- $\alpha$ and transforming Growth Factor- $\beta 1$ in different phases of wound healing, and also because of its antioxidant potential [74]. Therefore, the wound healing potential of the investigated species might be partly attributed to the presence of chlorogenic acid.

Table 6. Relative number of single cells that migrated into wound region (\%).

\begin{tabular}{cc}
\hline Extract & Wound Healing (\%) \\
\hline S. gummiferum-MeOH & $31.23 \pm 2.24$ \\
S. gummiferum-Water & $\mathrm{NE}$ \\
S. transcaucasicum-MeOH & $28.21 \pm 2.64$ \\
S. transcaucasicum-Water & $\mathrm{NE}$ \\
Control & $26.37 \pm 3.56$ \\
\hline
\end{tabular}

NE—no effect on migration (less than untreated control).

The discovery of new antimicrobial compounds is important in controlling bacterial infections caused by some pathogens that are rapidly becoming resistant to many existing antibiotics. In this context, folk medicine as an alternative form of health care, together with the development of microbial resistance to available antibiotics have led scientists to study the antimicrobial activity of medicinal plants [75].

In the present study, all extracts showed antibacterial activity against $S$. lugdunensis (MIC: $0.025-1 \mathrm{mg} / \mathrm{mL}$; MBC: $0.5-2 \mathrm{mg} / \mathrm{mL}$ ), although they were not as potent as the antibiotic streptomycin used as positive control in this study (MIC: $0.003 \mathrm{mg} / \mathrm{mL}$; MBC: $0.006 \mathrm{mg} / \mathrm{mL}$ ) (Table 7). The methanolic extract of S. gummiferum and the water extract of $S$. transcaucasicum demonstrated the highest and lowest antibacterial potential, respectively. It was interesting to note that the phytochemical composition of the investigated species could be linked to their antimicrobial activity. For instance, recent findings [76] have pointed out the antimicrobial activity of chlorogenic acid against the Salmonella species. The mechanism of antibacterial action involved damage of intracellular and outer membranes as well as disruption of cell metabolism, which resulted into death of the bacteria. Therefore, the obtained antimicrobial effect could be attributed to predominant constituents, including chlorogenic acid. 
Table 7. Antibacterial activity of extracts against $S$. lugdunensis, results are in $\mathrm{mg} / \mathrm{mL}$.

\begin{tabular}{ccc}
\hline \multirow{2}{*}{ Extract } & \multicolumn{2}{c}{ Staphylococcus lugdunensis } \\
\cline { 2 - 3 } & MIC & MBC \\
\hline S. gummiferum-MeOH & 0.025 & 0.5 \\
S. gummiferum-Water & 0.5 & 1 \\
S. transcaucasicum-MeOH & 0.5 & 1 \\
S. transcaucasicum-Water & 1 & 2 \\
Streptomycin & 0.003 & 0.006 \\
\hline
\end{tabular}

MIC: minimum inhibitory concentration; MBC: minimum bactericidal concentration.

The adhesion and invasion of S. lugdunensis to HaCaT cells after treatment with methanolic extract of S. gummiferum, which showed the most potent antibacterial activity among all the extracts, were also monitored. For instance, at MIC, the \% of adhesion and invasion were $<40 \%$ and $<90 \%$, respectively, while at $\mathrm{MBC}$, the $\%$ of adhesion and invasion were $<20 \%$ and $<70 \%$, respectively, compared to the untreated control, which showed $100 \%$ adhesion and invasion of S. lugdunensis (Figure 1).
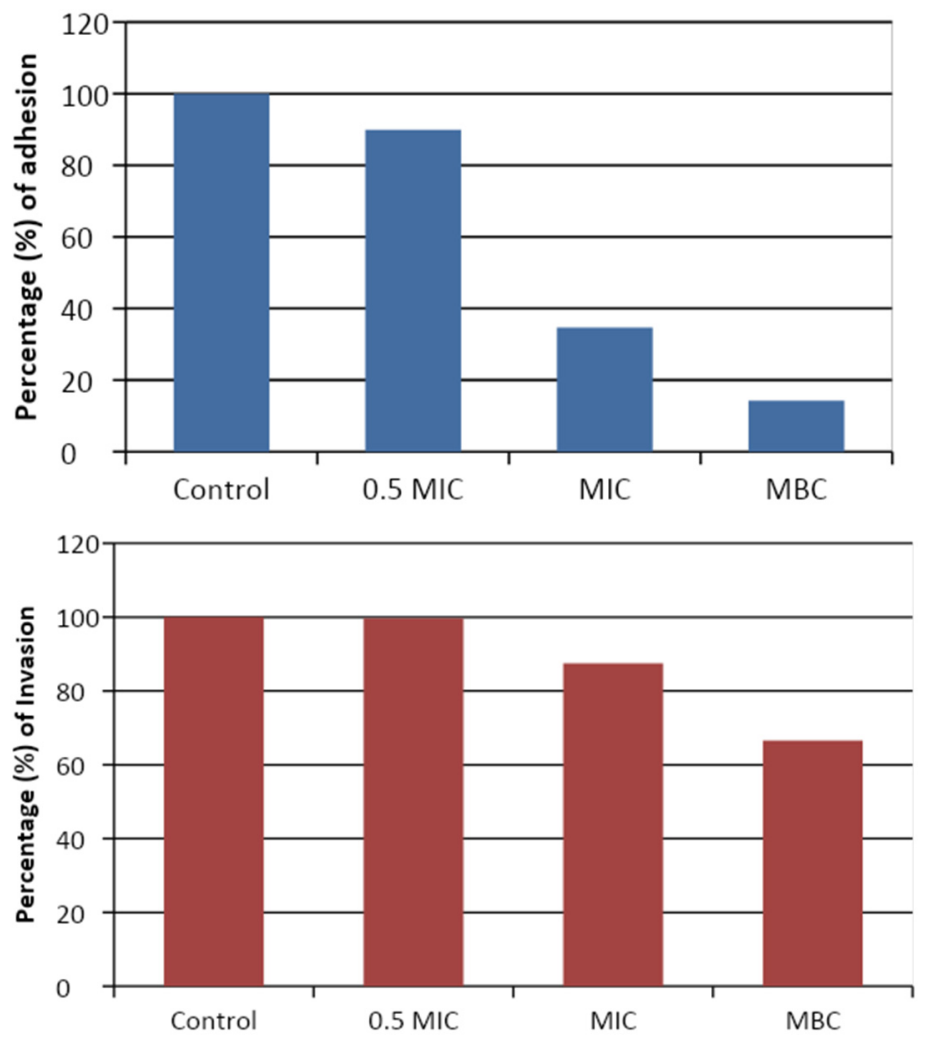

Figure 1. Adhesion and invasion (\%) of S. lugdunensis to HaCaT cells after treatment with S. gummiferum-MeOH (0.5 MIC-MBC) compared to the untreated control (100\%).

The members of the genus Seseli have been previously considered for antimicrobial studies. For instance, the essential oil of $S$. annuum showed antifungal activity against fifteen fungi (MIC values: 12.5-50 $\mu \mathrm{L} / \mathrm{mL}$ ) [9]. Similarly, the essential oil from the aerial parts of S. globiferum Vis. displayed significant activities both against bacteria (Pseudomonas aeruginosa, Micrococcus flavus, Listeria monocytogenes and Escherichia coli) and all investigated fungal species in a study conducted by Janaćković et al. [36]. Moreover, in the study of Stankov-Jovanović et al. [37], the inhibitory and microbicidal concentration ranges of the tested extracts of S. rigidum against the bacteria Escherichia coli, Pseudomonas aeruginosa, Staphylococcus aureus, Bacillus cereus, and fungi Candida albicans and Aspergillus niger were $0.01-1.50 \mathrm{mg} / \mathrm{mL}$ and $0.02-3.00 \mathrm{mg} / \mathrm{mL}$, respectively. It was also reported by Tosun, et al. [77] that the n-hexane extracts of S. resinosum and S. hartvigii and the essential 
oil of S. gummiferum subsp. gummiferum displayed antimicrobial activity against two strains of Staphylococcus aureus. Furthermore, Ozturk and Ercisli [78] investigated the antibacterial properties of the methanolic extract of $S$. libanotis against several strains and remarkable antibacterial abilities were reported (>14 $\mathrm{mm}$ inhibition zone).

\section{Conclusions}

This study is the first comparative report on the biological and chemical properties of S. gummiferum and S. transcaucasicum water and methanolic extracts obtained from the aerial parts of the plants. The studied Seseli extracts were found to possess multitargeted pharmacological potentials, as evidenced in various assays performed. For instance, they displayed antioxidant effects and acted as inhibitors of enzymes having a key role in the pathogenesis of diseases such as diabetes, Alzheimer's disease and skin hyperpigmentation. Following their cytotoxic studies on $\mathrm{HaCaT}$ cells, the extracts were also tested for wound healing potential, whereby only the methanolic extracts showed very little effect. Moreover, they displayed inhibitory and bactericidal action on the bacterium S. lugdunensis. The methanolic extract of $S$. gummiferum which showed the highest antibacterial potency, was also found to inhibit adhesion and invasion of $S$. lugdunensis to HaCaT cells. The extracts were also revealed to be rich sources of polyphenolic compounds. The methanolic extracts in particular were noted to contain chlorogenic acid and narcissin in greater quantity compared to the water extracts. However, choosing an appropriate solvent for the extraction of plant materials is of high importance for the yield of certain compounds. Since the biological activities of the extracts are linked with the quantity of compounds present and their ratios in the extracts, it might be concluded that biological activity of the extracts is directly dependent on the plant species and extraction solvents used. Overall, this study demonstrated the extracts to exhibit important biological potentials and could be exploited as health promoting agents. Nevertheless, in vivo studies would be helpful to further investigate the toxicity and safe use of these extracts to benefit from their healing potentials.

Supplementary Materials: The following are available online at https:/ / www.mdpi.com/article/10 .3390/antiox10101510/s1, Figure S1: The UHPLC-DAD chromatograms at $280 \mathrm{~nm}$, with some labeled peaks of quantified polyphenols; (1) gallic acid; (2) chlorogenic acid; (3) isoorientin; (4) rutin; (5) $p$ coumaric acid; (6) isoquercetin; (7) narcissin; (8) rosmarinic acid; (A) S. gummiferum MeOH extract; (B) S. gummiferum water extract; (C) S. lugdunensis MeOH extract; (D) S. lugdunensis water extract.

Author Contributions: Conceptualization, G.Z., D.S.; methodology, M.I., M.Y.P., U.G.; software, G.Z.; validation, G.Z., M.F.M.; formal analysis, G.Z.; investigation, G.Z., D.S., M.F.M.; resources, G.Z., M.Y.P.; data curation, D.S.; writing—original draft preparation, M.F.M., B.S.J.; writing-review and editing, G.Z., M.G., D.M.; visualization, G.Z.; supervision, M.G., D.M.; project administration, G.Z.; funding acquisition, D.M. All authors have read and agreed to the published version of the manuscript.

Funding: This study was supported financially under Project (Project No: 20401129) from the Selcuk University Scientific Research Foundation (BAP).

Institutional Review Board Statement: No applicable.

Informed Consent Statement: No applicable.

Data Availability Statement: All data is contained within the article and Supplementary Materials.

Conflicts of Interest: The authors declare no conflict of interest.

\section{References}

1. Cabral, C.; Lemos, M.; Cavaleiro, C.; Cruz, M.; Salgueiro, L. Essential oil of Seseli tortuosum L. from Portugal: Safety and anti-inflammatory potential evaluation. Arab. J. Med. Aromat. Plants 2015, 1, 31-43.

2. Küpeli, E.; Tosun, A.; Yesilada, E. Anti-inflammatory and antinociceptive activities of Seseli L. species (Apiaceae) growing in Turkey. J. Ethnopharmacol. 2006, 104, 310-314. [CrossRef] [PubMed] 
3. Sahranavard, S.; Ghafari, S.; Mosaddegh, M. Medicinal plants used in Iranian traditional medicine to treat epilepsy. Seizure 2014, 23, 328-332. [CrossRef] [PubMed]

4. Ilić, M.D.; Jovanović, V.P.S.; Mitić, V.D.; Jovanović, O.P.; Mihajilov-Krstev, T.M.; Marković, M.S.; Stojanović, G.S. Comparison of chemical composition and biological activities of Seseli rigidum fruit essential oils from Serbia. Open Chem. 2015, 13, 13.42-51. [CrossRef]

5. Abbaskhan, A.; Choudhary, M.I.; Ghayur, M.N.; Parween, Z.; Shaheen, F.; Gilani, A.U.H.; Maruyama, T.; Iqbal, K.; Tsuda, Y. Biological activities of Indian celery, Seseli diffusum (Roxb. ex Sm.) Sant. \& Wagh. Phytother. Res. 2012, 26, 783-786. [PubMed]

6. Tosun, A.; Akkol, E.K.; Yeşilada, E. Anti-inflammatory and antinociceptive activity of coumarins from Seseli gummiferum subsp. corymbosum (Apiaceae). Z. Nat. C 2009, 64, 56-62.

7. Chun, J.; Tosun, A.; Kim, Y.S. Anti-inflammatory effect of corymbocoumarin from Seseli gummiferum subsp. corymbosum through suppression of NF- $\mathrm{BB}$ signaling pathway and induction of HO-1 expression in LPS-stimulated RAW 264.7 cells. Int. Immunopharmacol. 2016, 31, 207-215. [CrossRef]

8. Cinar, A.S.; Bakar-Ates, F.; Onder, A. Seseli petraeum M. Bieb. (Apiaceae) Significantly inhibited cellular growth of A549 lung cancer cells through G0/G1 cell cycle arrest. An. Acad. Bras. Cienc. 2020, 92. [CrossRef]

9. Milosavljević, S.; Tešević, V.; Vučković, I.; Jadranin, M.; Vajs, V.; Soković, M.; Janaćković, P.; Jovanović, A. Composition and antifungal activity of the essential oil of Seseli annuum wild-growing in Serbia. Fitoterapia 2007, 78, 319-322. [CrossRef]

10. Siljegović, J.; Glamoclija, J.; Soković, M.; Vucković, I.; Tesević, V.; Milosavljević, S.; Stesević, D. Composition and antimicrobial activity of Seseli montanum subsp. tommasinii essential oil. Nat. Prod. Commun. 2011, 6, 263-266.

11. Marčetić, M.; Božić, D.; Milenković, M.; Lakušić, B.; Kovačević, N. Chemical composition and antimicrobial activity of essential oil of different parts of Seseli rigidum. Nat. Prod. Commun. 2012, 7. [CrossRef]

12. Widelski, J.; Melliou, E.; Fokialakis, N.; Magiatis, P.; Glowniak, K.; Chinou, I. Coumarins from the fruits of Seseli devenyense. J. Nat. Prod. 2005, 68, 1637-1641. [CrossRef]

13. Tosun, A.; Baba, M.; Bahadir, O.; Okuyama, T. Coumarins isolated from the roots of Seseli resinosum. in Turkey. Pharm. Biol. 2006, 44, 528-533. [CrossRef]

14. Tosun, A.; Baba, M.; Okuyama, T. HPLC analysis of coumarins in Turkish Seseli species (Umbelliferae). J. Nat. Med. 2007, 61, 402-405. [CrossRef]

15. Zhang, L.; Tosun, A.; Baba, M.; Okada, Y.; Wu, L.; Okuyama, T. Coumarins from Seseli Hartvigii. Nat. Prod. Commun. 2010, 5. [CrossRef]

16. Khan, S.; Shehzad, O.; Lee, K.J.; Tosun, A.; Kim, Y.S. Anti-inflammatory properties of samidin from Seseli resinosum through suppression of NF-kB and AP-1-mediated-genes in LPS-stimulated RAW 264.7 cells. Arch. Pharm. Res. 2014, 37, 1496-1503. [CrossRef] [PubMed]

17. Khan, S.; Shehzad, O.; Cheng, M.-S.; Li, R.-J.; Kim, Y.S. Pharmacological mechanism underlying anti-inflammatory properties of two structurally divergent coumarins through the inhibition of pro-inflammatory enzymes and cytokines. J. Inflamm. 2015, 12, 1-11. [CrossRef]

18. Vučković, I.; Trajković, V.; Macura, S.; Tešević, V.; Janaćković, P.A.; Milosavljević, S. A novel cytotoxic lignan from Seseli annuum L. Phytother. Res. 2007, 21, 790-792. [CrossRef] [PubMed]

19. Grochowski, D.M.; Uysal, S.; Aktumsek, A.; Granica, S.; Zengin, G.; Ceylan, R.; Locatelli, M.; Tomczyk, M. In vitro enzyme inhibitory properties, antioxidant activities, and phytochemical profile of Potentilla thuringiaca. Phytochem. Lett. 2017, 20, 365-372. [CrossRef]

20. Uysal, S.; Zengin, G.; Locatelli, M.; Bahadori, M.B.; Mocan, A.; Bellagamba, G.; De Luca, E.; Mollica, A.; Aktumsek, A. Cytotoxic and enzyme inhibitory potential of two Potentilla species (P. speciosa L. and P. reptans Willd.) and their chemical composition. Front. Pharmacol. 2017, 8, 290. [CrossRef]

21. Radović, M.; Milatović, D.; Tešić, Ž.; Tosti, T.; Gašić, U.; Dojčinović, B.; Zagorac, D.D. Influence of rootstocks on the chemical composition of the fruits of plum cultivars. J. Food Compos. Anal. 2020, 92, 103480. [CrossRef]

22. Božunović, J.; Živković, S.; Gašić, U.; Glamočlija, J.; Ćirić, A.; Matekalo, D.; Šiler, B.; Soković, M.; Tešić, Ž.; Mišić, D. In vitro and in vivo transformations of Centaurium erythraea secoiridoid glucosides alternate their antioxidant and antimicrobial capacity. Ind. Crop. Prod. 2018, 111, 705-721. [CrossRef]

23. Stojković, D.; Drakulić, D.; Gašić, U.; Zengin, G.; Stevanović, M.; Rajčević, N.; Soković, M. Ononis spinosa L. an edible and medicinal plant: UHPLC-LTQ-Orbitrap/MS chemical profiling and biological activities of the herbal extract. Food Funct. 2020, 11, 7138-7151. [CrossRef] [PubMed]

24. Ahmed, G.F.; Elkhatib, W.F.; Noreddin, A.M. Inhibition of Pseudomonas aeruginosa PAO1 adhesion to and invasion of A549 lung epithelial cells by natural extracts. J. Infect. Public Health 2014, 7, 436-444. [CrossRef] [PubMed]

25. Stojković, D.S.; Kovačević-Grujičić, N.; Reis, F.S.; Davidović, S.; Barros, L.; Popović, J.; Petrović, I.; Pavić, A.; Glamočlija, J.; Ćirić, A. Chemical composition of the mushroom Meripilus giganteus Karst. and bioactive properties of its methanolic extract. LWT-Food Sci. Technol. 2017, 79, 454-462. [CrossRef]

26. Kostić, M.; Smiljković, M.; Petrović, J.; Glamočlija, J.; Barros, L.; Ferreira, I.C.; Ćirić, A.; Soković, M. Chemical, nutritive composition and a wide range of bioactive properties of honey mushroom Armillaria mellea (Vahl: Fr.) Kummer. Food Funct. 2017, 8, 3239-3249. [CrossRef] 
27. Matejić, J.; Džamić, A.; Mihajilov-Krstev, T.; Ranđelović, V.; Krivošej, Z.; Marin, P. Total phenolic content, flavonoid concentration, antioxidant and antimicrobial activity of methanol extracts from three Seseli L. taxa. Open Life Sci. 2012, 7, 1116-1122. [CrossRef]

28. Jakovljević, D.; Vasić, S.; Stanković, M.; Čomić, L.; Topuzović, M. In vitro biological activity of secondary metabolites from Seseli rigidum Waldst. et Kit. (Apiaceae). Acta Biol. Hung. 2015, 66, 395-405. [CrossRef]

29. Sikuten, I.; Stambuk, P.; Tomaz, I.; Marchal, C.; Kontic, J.K.; Lacombe, T.; Maletic, E.; Preiner, D. Discrimination of genetic and geographical groups of grape varieties (Vitis vinifera L.) based on their polyphenolic profiles. J. Food Comp. Anal. 2021, $102,104062$. [CrossRef]

30. Santos, V.H.M.; Minatel, I.O.; Lima, G.P.P.; Silva, R.M.G.; Chen, C.-Y.O. Antioxidant capacity and phytochemical characterization of Spathodea campanulata growing in different climatic zones in Brazil. Biocatal. Agric. Biotechnol. 2020, 24, 101536. [CrossRef]

31. Sánchez-Rangel, J.C.; Benavides, J.; Heredia, J.B.; Cisneros-Zevallos, L.; Jacobo-Velázquez, D.A. The Folin-Ciocalteu assay revisited: Improvement of its specificity for total phenolic content determination. Anal. Methods 2013, 5, 5990-5999. [CrossRef]

32. De Sotillo, D.V.R.; Hadley, M. Chlorogenic acid modifies plasma and liver concentrations of: Cholesterol, triacylglycerol, and minerals in (fa/fa) Zucker rats. J. Nutr. Biochem. 2002, 13, 717-726. [CrossRef]

33. Nicasio, P.; Aguilar-Santamaría, L.; Aranda, E.; Ortiz, S.; González, M. Hypoglycemic effect and chlorogenic acid content in two Cecropia species. Phytother. Res. 2005, 19, 661-664. [CrossRef] [PubMed]

34. De Sotillo, D.V.R.; Hadley, M.; Sotillo, J.E. Insulin receptor exon 11+/ - is expressed in Zucker (fa/fa) rats, and chlorogenic acid modifies their plasma insulin and liver protein and DNA. J. Nutr. Biochem. 2006, 17, 63-71. [CrossRef]

35. Dogan, E.; Duman, H.; Tosun, A.; Kürkçuoglu, M.; Baser, K. Essential oil composition of the fruits of Seseli resinosum Freyn et Sint. and Seseli tortuosum L. growing in Turkey. J. Essen. Oil Res. 2006, 18, 57-59. [CrossRef]

36. Janaćković, P.; Soković, M.; Vujisić, L.; Vajs, V.; Vucković, I.; Krivošej, Z.; Marin, P.D. Composition and antimicrobial activity of Seseli globiferum essential oil. Nat. Prod. Commun. 2011, 6, 1163-1166. [CrossRef]

37. Stankov-Jovanović, V.; Ilić, M.; Mitić, V.; Mihajilov-Krstev, T.; Simonović, S.; Mandić, S.N.; Tabet, J.; Cole, R. Secondary metabolites of Seseli rigidum: Chemical composition plus antioxidant, antimicrobial and cholinesterase inhibition activity. J. Pharm. Biomed. Anal. 2015, 111, 78-90. [CrossRef]

38. Tosun, A.; Chun, J.; Jerković, I.; Marijanović, Z.; Fenu, M.A.; Aslan, S.S.; Tuberoso, C.I.; Kim, Y.S. Chemical profiles and antiinflammatory activity of the essential oils from Seseli gummiferum and Seseli corymbosum subsp. corymbosum. Nat. Prod. Commun. 2016, 11. [CrossRef]

39. Kürkçüoğlu, M.; Tabanca, N.; Ali, A.; Khan, I.A.; Duran, A.; Başer, K. Chemical Composition of a new taxon, Seseli gummiferum subsp. ilgazense, and its larvicidal activity against Aedes aegypti. Rec. Nat. Prod. 2017, 12, 184-189. [CrossRef]

40. Pizzino, G.; Irrera, N.; Cucinotta, M.; Pallio, G.; Mannino, F.; Arcoraci, V.; Squadrito, F.; Altavilla, D.; Bitto, A. Oxidative stress: Harms and benefits for human health. Oxid. Med. Cell. Longev. 2017, 2017. [CrossRef]

41. Sharifi-Rad, M.; Anil Kumar, N.V.; Zucca, P.; Varoni, E.M.; Dini, L.; Panzarini, E.; Rajkovic, J.; Tsouh Fokou, P.V.; Azzini, E.; Peluso, I. Lifestyle, oxidative stress, and antioxidants: Back and forth in the pathophysiology of chronic diseases. Front. Physiol. 2020, 11, 694. [CrossRef] [PubMed]

42. Kasote, D.M.; Katyare, S.S.; Hegde, M.V.; Bae, H. Significance of antioxidant potential of plants and its relevance to therapeutic applications. Int. J. Biol. Sci. 2015, 11, 982. [CrossRef] [PubMed]

43. Elessawy, F.M.; Vandenberg, A.; El-Aneed, A.; Purves, R.W. An untargeted metabolomics approach for correlating pulse crop seed coat polyphenol profiles with antioxidant capacity and iron chelation ability. Molecules 2021, 26, 3833. [CrossRef]

44. Önder, A.; Cinar, A.S.; Sarialtin, S.Y.; Izgi, M.N.; Çoban, T. Evaluation of the antioxidant potency of Seseli L. species (Apiaceae). Turk. J. Pharm. Sci. 2020, 17, 197. [CrossRef]

45. Foti, M.C. Use and Abuse of the DPPH• Radical. J. Agric. Food Chem. 2015, 63, 8765-8776. [CrossRef] [PubMed]

46. Bibi Sadeer, N.; Montesano, D.; Albrizio, S.; Zengin, G.; Mahomoodally, M.F. The versatility of antioxidant assays in food science and safety-Chemistry, applications, strengths, and limitations. Antioxidants 2020, 9, 709. [CrossRef]

47. Liang, N.; Kitts, D.D. Role of chlorogenic acids in controlling oxidative and inflammatory stress conditions. Nutrients 2015, 8, 16. [CrossRef]

48. Naveed, M.; Hejazi, V.; Abbas, M.; Kamboh, A.A.; Khan, G.J.; Shumzaid, M.; Ahmad, F.; Babazadeh, D.; Xia, F.; ModarresiGhazani, F.; et al. Chlorogenic acid (CGA): A pharmacological review and call for further research. Biomed. Pharmacother. 2018, 97, 67-74. [CrossRef] [PubMed]

49. Novaes, P.; Torres, P.B.; Cornu, T.A.; de Carvalho Lopes, J.; Ferreira, M.J.P.; Dos Santos, D.Y.A.C. Comparing antioxidant activities of flavonols from Annona coriacea by four approaches. S. Afr. J. Bot. 2019, 123, 253-258. [CrossRef]

50. He, J.; Xu, L.; Yang, L.; Wang, X. Epigallocatechin gallate is the most effective catechin against antioxidant stress via hydrogen peroxide and radical scavenging activity. Med. Sci. Monit. 2018, 24, 8198-8206. [CrossRef]

51. Chen, J.; Yang, J.; Ma, L.; Li, J.; Shahzad, N.; Kim, C.K. Structure-antioxidant activity relationship of methoxy, phenolic hydroxyl, and carboxylic acid groups of phenolic acids. Sci. Rep. 2020, 10, 2611. [CrossRef] [PubMed]

52. Ouertani, A.; Neifar, M.; Ouertani, R. Effectiveness of enzyme inhibitors in biomedicine and pharmacotherapy. Adv. Tissue Eng. Regen. Med. Open Access 2019, 5, 85-90.

53. Sharma, K. Cholinesterase inhibitors as Alzheimer's therapeutics. Mol. Med. Rep. 2019, 20, 1479-1487. [CrossRef] [PubMed] 
54. Oboh, G.; Agunloye, O.M.; Akinyemi, A.J.; Ademiluyi, A.O.; Adefegha, S.A. Comparative study on the inhibitory effect of caffeic and chlorogenic acids on key enzymes linked to Alzheimer's disease and some pro-oxidant induced oxidative stress in rats' brain-in vitro. Neurochem. Res. 2013, 38, 413-419. [CrossRef] [PubMed]

55. Gülçin, İ.; Scozzafava, A.; Supuran, C.T.; Koksal, Z.; Turkan, F.; Çetinkaya, S.; Bingöl, Z.; Huyut, Z.; Alwasel, S.H. Rosmarinic acid inhibits some metabolic enzymes including glutathione S-transferase, lactoperoxidase, acetylcholinesterase, butyrylcholinesterase and carbonic anhydrase isoenzymes. J. Enzym. Inhib. Med. Chem. 2016, 31, 1698-1702. [CrossRef] [PubMed]

56. Orhan, I.; Kartal, M.; Tosun, F.; Sener, B. Screening of various phenolic acids and flavonoid derivatives for their anticholinesterase potential. Z. Nat. C. J. Biosci. 2007, 62, 829-832. [CrossRef]

57. Ademosun, A.O.; Oboh, G.; Bello, F.; Ayeni, P.O. Antioxidative properties and effect of quercetin and its glycosylated form (rutin) on acetylcholinesterase and butyrylcholinesterase activities. J. Evid. Based. Complement. Altern. Med. 2016, 21, Np11-Np17. [CrossRef]

58. Panzella, L.; Napolitano, A. Natural and bioinspired phenolic compounds as tyrosinase inhibitors for the treatment of skin hyperpigmentation: Recent advances. Cosmetics 2019, 6, 57. [CrossRef]

59. Arung, E.T.; Shimizu, K.; Kondo, R. Artocarpus plants as a potential source of skin whitening agents. Nat. Prod. Comm. 2011, 6, 1397-1402. [CrossRef]

60. Hanif, N.; Al-Shami, A.M.A.; Khalid, K.A.; Hadi, H. Plant-based skin lightening agents: A review. J. Phytopharm. 2020, 9, 54-60. [CrossRef]

61. Mocan, A.; Zengin, G.; Simirgiotis, M.; Schafberg, M.; Mollica, A.; Vodnar, D.C.; Crişan, G.; Rohn, S. Functional constituents of wild and cultivated Goji (L. barbarum L.) leaves: Phytochemical characterization, biological profile, and computational studies. J. Enzym. Inhib. Med. Chem. 2017, 32, 153-168. [CrossRef] [PubMed]

62. Maruyama, H.; Kawakami, F.; Lwin, T.-T.; Imai, M.; Shamsa, F. Biochemical characterization of ferulic acid and caffeic acid which effectively inhibit melanin synthesis different mechanisms in B16 melanoma cells. Biol. Pharm. Bull. 2018, 41, 806-810. [CrossRef]

63. Zuo, A.-R.; Dong, H.-H.; Yu, Y.-Y.; Shu, Q.-L.; Zheng, L.-X.; Yu, X.-Y.; Cao, S.-W. The antityrosinase and antioxidant activities of flavonoids dominated by the number and location of phenolic hydroxyl groups. Chin. Med. 2018, 13, 51. [CrossRef] [PubMed]

64. Tundis, R.; Loizzo, M.; Menichini, F. Natural products as $\alpha$-amylase and $\alpha$-glucosidase inhibitors and their hypoglycaemic potential in the treatment of diabetes: An update. Mini Rev. Med. Chem. 2010, 10, 315-331. [CrossRef]

65. Trinh, B.T.; Staerk, D.; Jäger, A.K. Screening for potential $\alpha$-glucosidase and $\alpha$-amylase inhibitory constituents from selected Vietnamese plants used to treat type 2 diabetes. J. Ethnopharmacol. 2016, 186, 189-195. [CrossRef]

66. Gajbhiye, R.L.; Ganapathy, A.; Jaisankar, P. A review of $\alpha$-glucosidase and $\alpha$-amylase inhibitors for Type 2 diabetes isolated from some important Indian medicinal plants. Ann. Clin. Pharmacol. Ther. 2018, 1, 1003-1013.

67. Zheng, Y.; Yang, W.; Sun, W.; Chen, S.; Liu, D.; Kong, X.; Tian, J.; Ye, X. Inhibition of porcine pancreatic $\alpha$-amylase activity by chlorogenic acid. J. Funct. Food. 2019, 64, 103587. [CrossRef]

68. McCue, P.P.; Shetty, K. Inhibitory effects of rosmarinic acid extracts on porcine pancreatic amylase in vitro. Asia Pac. J. Clin. Nutr. 2004, 13, 101-106. [PubMed]

69. Oboh, G.; Ogunsuyi, O.B.; Ogunbadejo, M.D.; Adefegha, S.A. Influence of gallic acid on $\alpha$-amylase and $\alpha$-glucosidase inhibitory properties of acarbose. J. Food Drug Anal. 2016, 24, 627-634. [CrossRef]

70. Tadera, K.; Minami, Y.; Takamatsu, K.; Matsuoka, T. Inhibition of $\alpha$-glucosidase and $\alpha$-amylase by flavonoids. J. Nutr. Sci. Vitaminol. 2006, 52, 149-153. [CrossRef]

71. Hernandes, L.C.; Machado, A.R.T.; Tuttis, K.; Ribeiro, D.L.; Aissa, A.F.; Dévoz, P.P.; Antunes, L.M.G. Caffeic acid and chlorogenic acid cytotoxicity, genotoxicity and impact on global DNA methylation in human leukemic cell lines. Genet. Mol. Biol. 2020, 43. [CrossRef]

72. Jiang, Y.; Kusama, K.; Satoh, K.; Takayama, F.; Watanabe, S.; Sakagami, H. Induction of cytotoxicity by chlorogenic acid in human oral tumor cell lines. Phytomedicine 2000, 7, 483-491. [CrossRef]

73. Moghadam, S.E.; Ebrahimi, S.N.; Salehi, P.; Moridi Farimani, M.; Hamburger, M.; Jabbarzadeh, E. Wound healing potential of chlorogenic acid and Myricetin-3-O- $\beta$-Rhamnoside isolated from Parrotia persica. Molecules 2017, 22, 1501. [CrossRef] [PubMed]

74. Chen, W.-C.; Liou, S.-S.; Tzeng, T.-F.; Lee, S.-L.; Liu, I.-M. Effect of topical application of chlorogenic acid on excision wound healing in rats. Planta Med. 2013, 79, 616-621. [CrossRef] [PubMed]

75. Kumarasamy, Y.; Cox, P.J.; Jaspars, M.; Nahar, L.; Sarker, S.D. Screening seeds of Scottish plants for antibacterial activity. J. Ethnopharmacol. 2002, 83, 73-77. [CrossRef]

76. Sun, Z.; Zhang, X.; Wu, H.; Wang, H.; Bian, H.; Zhu, Y.; Xu, W.; Liu, F.; Wang, D.; Fu, L. Antibacterial activity and action mode of chlorogenic acid against Salmonella enteritidis, a foodborne pathogen in chilled fresh chicken. World J. Microbiol. Biotechnol. 2020, 36, 1-10. [CrossRef]

77. Tosun, A.; Özkal, N.; Yıldız, S. Antımıcrobıal actıvıty screenıng of some Seseli L. specıes growıng in Turkey. J. Pharm. Ank. Univ. 2004, 33, 151-155.

78. Ozturk, S.; Ercisli, S. Chemical composition and in vitro antibacterial activity of Seseli libanotis. World J. Microbiol. Biotechnol. 2006, 22, 261-265. [CrossRef] 